\title{
Short communication: Feed iodine concentrations on farms with contrasting levels of iodine in milk
}

\author{
S. I. Borucki Castro, ${ }^{*}$ P. Lacasse, ${ }^{*}$ A. Fouquet, $†$ F. Beraldin, $\dagger$ A. Robichaud, $\dagger$ and R. Berthiaume ${ }^{* 1}$ \\ *Dairy and Swine Research and Development Centre, Agriculture and Agri-Food Canada, 2000 College St., Sherbrooke, QC, Canada J1M 1 Z3 \\ †Food Directorate, Health Products and Food Branch, Health Canada, 1001 St-Laurent St. W., Longueuil, QC, Canada J4K 1C7
}

\begin{abstract}
In a previous study, milk iodine concentration from 501 farms across Canada was found to vary considerably and appeared to be influenced by feeding practices. Farms with contrasting levels of milk iodine from a subset of 200 participating farms were used to determine the relationship between milk iodine concentration and the concentration of this mineral in different feeds and complete diets given to lactating dairy cows. The 30 farms with the lowest levels of iodine in milk (low group) and the 30 farms with the highest levels (high group) were selected. Samples of bulk tank milk, all feed ingredients, and water were collected. Additionally, each farmer completed a questionnaire providing information on feeding management. The iodine offered on each of the farms was estimated from the amount of the feed in the diet recommended by the Ration'L software (Valacta, Ste-Anne-de-Bellevue, QC, Canada) and the iodine concentration in the feed sampled and analyzed using inductively coupled plasma mass spectrometry. The dietary concentration of iodine offered daily was $33 \%$ lower for the low group compared with the high group; that is, $1.20 \pm 0.099$ versus $1.81 \pm$ $0.195 \mathrm{mg} / \mathrm{kg}$ of dry matter (DM), respectively. Milk iodine concentrations averaged $146 \pm 13.9 \mu \mathrm{g} / \mathrm{kg}$ for the low group and $487 \pm 44.6 \mu \mathrm{g} / \mathrm{kg}$ for the high group. A linear relationship was found between dietary iodine concentration and milk iodine level, as follows: milk iodine $(\mu \mathrm{g} / \mathrm{kg})=145( \pm 66.9)+113( \pm 39.4)$ dietary iodine concentration $(\mathrm{mg} / \mathrm{kg} \mathrm{DM})$. However, the low $\mathrm{R}^{2}$ value $(0.15)$ indicates that other factors, such as milking management and the presence of goitrogens, may have affected the concentrations of iodine in milk. Forages supplied approximately $17 \%$ of iodine requirements in the average lactating cow diet. Therefore, variations in the iodine content of forages are unlikely to cause iodine overfeeding. In contrast, $27 \%$ of the mineral mix samples presented iodine concentrations $>100,000 \mu \mathrm{g} /$
\end{abstract}

Received August 11, 2010.

Accepted April 18, 2011.

${ }^{1}$ Corresponding author: Robert.Berthiaume@agr.gc.ca $\mathrm{kg}$ of DM (and up to $322,000 \mu \mathrm{g} / \mathrm{kg}$ of DM). More than $85 \%$ of the farms tested were feeding iodine levels higher than the dietary iodine recommendations $(0.5 \mathrm{mg}$ of iodine $/ \mathrm{kg}$ of $\mathrm{DM}$ ). Iodine supplements should be used with caution in lactating cow diets.

Key words: food safety, milk quality, dairy cow

\section{Short Communication}

Cow milk has become one of the most important sources of iodine for human nutrition in several developed countries (Dahl et al., 2003; Li et al., 2006; Schöne et al., 2009). However, the tolerable iodine intake level could easily be exceeded with high milk iodine concentrations (Scientific Committee on Food, 2002; Flachowsky, 2007; Flachowsky et al., 2007). In humans, a rapid increase in iodine intakes increases the risk of iodine toxicity in susceptible individuals and young children (Roti and Uberti, 2001). Therefore, the European Food Safety Authority (2005) suggested that the maximum iodine content in dairy cattle rations be set at $4,000 \mu \mathrm{g} / \mathrm{kg}$ of feed (as fed, $88 \% \mathrm{DM}$ ). The European Union Regulation EC 1459/2005 (European Union, 2005) followed the proposal and lowered the maximum iodine concentration in dairy feedstuffs from 10,000 to $5,000 \mu \mathrm{g} / \mathrm{kg}$ (as fed, $88 \% \mathrm{DM}$ ).

A Health Canada study on retail milk found that the average iodine content of Canadian milk is high: $393 \pm$ $150 \mu \mathrm{g} / \mathrm{kg}$ (A. Robichaud, unpublished results). These levels of iodine are in the same range as those found in 2007 in 500 samples of bulk tank milk from farms across Canada (304 $\pm 188 \mu \mathrm{g} / \mathrm{kg}$; Borucki Castro et al., 2010). These findings indicate that most of the iodine in the milk delivered to the consumer is already present at the farm gate. In our previous study, one of the factors associated with farms presenting high milk iodine levels was the type of ration used, together with other factors of milking management. The transfer of iodine from feeds to milk ranges from 7 to $27 \%$, depending on the amount fed to the animal (Kaufmann et al., 1998; Norouzian et al., 2009; Moschini et al., 2010). Special caution is required in diet formulation of lactating dairy cows because feeding iodine in excess will immediately result in higher concentrations of iodine in 
milk. Forages, which constitute $50 \%$ or more of the DM consumed by the cow, are assumed in diet formulation databases (e.g., NRC, 2001) to contain no iodine. The objective of this study was to investigate the iodine content in forages and other dairy cow feedstuffs, and to determine their contribution to the total iodine consumed by the animal. Furthermore, based on the analysis of the levels of iodine in bulk-tank milk and on the different feeds sampled, the relationship between the total iodine offered and the levels of iodine in milk was determined.

The farms for this study were selected based on milk iodine concentrations recorded in a previous study (Borucki Castro et al., 2010). Of the 200 dairy farms that had been sampled in the province of Quebec (Canada), 30 farms with the highest iodine levels (high group) and 30 farms with lowest iodine levels (low group) were chosen. Samples of the feed ingredients and TMR fed to lactating cows were collected, together with water and milk samples from the bulk tank. In addition, farmers were asked to complete a questionnaire to characterize their farms' feeding programs and milking management. Of the 60 farms targeted, 54 were sampled and 52 completed the questionnaire. All of the selected farms were clients of the dairy herd improvement program run by Valacta Dairy Production Centre of Expertise (Ste-Anne-de-Bellevue, QC, Canada), and the samples were collected by Valacta representatives during regular visits between April and June 2008.

Milk samples were analyzed at Health Canada (Longueuil, QC, Canada) in a laboratory accredited by the Standards Council of Canada. Total iodine concentration (organic and inorganic) was determined using the method of Benkhedda et al. (2009) by inductively coupled plasma mass spectrometry (7500 series model, Agilent Technologies, Santa Clara, CA) optimized for raw milk samples. Prior to analysis, samples were digested in a closed microwave system with a mixture of perchloric and nitric acids. The detection limit was $12 \mathrm{ng} / \mathrm{g}$ for a $0.5 \mathrm{-g}$ sample, with precisions of 4.0 and $2.2 \%$ obtained for 10 replicate measurements of 50 and $1,000 \mathrm{ng} / \mathrm{g}$ standards, respectively.

Descriptive statistics, regression analysis, and group differences (low vs. high) were determined using $t$-tests and ANOVA with the Data Analysis Toolpak of Microsoft Office Excel (Microsoft Corp., Redmond, WA). Feed ingredients are presented in this paper using descriptive statistics and graphical distribution. Feeds were classified according to the way they were reported in the questionnaires (i.e., as registered supplements, custom-made concentrates, or mineral mixes). Bulktank milk iodine was related to dietary iodine concentration in the lactating cow group, which was calculated for each of the farms based on (1) the amount of feed offered (Valacta Ration'L formulation software) and (2) the iodine concentration of the different feeds sampled and analyzed by Health Canada's laboratory. Farms were grouped according to iodine concentration in the diet $(\mathrm{mg} / \mathrm{kg}$ of $\mathrm{DM})$ compared with the level recommended by the NRC $(2001 ; 0.5 \mathrm{mg} / \mathrm{kg}$ of DM). Five groups were formed: (1) $100 \%$ of the recommended value $(0.30$ to $0.74 \mathrm{mg} / \mathrm{kg}$ of $\mathrm{DM}) ;(2)$ twice the recommended value ( 0.75 to $1.24 \mathrm{mg} / \mathrm{kg}$ of DM); (3) 3 times the recommended value (1.25 to $1.74 \mathrm{mg} / \mathrm{kg}$ of $\mathrm{DM})$; (4) 4 times the recommended value ( 1.75 to $2.24 \mathrm{mg} /$ $\mathrm{kg}$ of DM); and (5) 5 times the recommended value or more $(>2.25 \mathrm{mg} / \mathrm{kg}$ of DM).

In total, $96 \%$ of the samples received were successfully analyzed; $38 \%$ were forages (hay, silage, and haylage), $22 \%$ were supplements, $20 \%$ mineral mixes, $13 \%$ grain samples, $4 \%$ soybean products, and $3 \%$ samples of TMR. Iodine levels in forages, grains, and soy products are presented in Table 1. Iodine levels in plant sources are highly variable; they depend on proximity to the sea, plant species and strain, and climatic and seasonal conditions (Underwood and Suttle, 1999). As an example, the variation between cyanogenic and noncyanogenic strains of white clover grown in the same area of New Zealand varied from 200 to $40 \mu \mathrm{g} /$ $\mathrm{kg}$ of iodine, respectively. The iodine in the plant appears to be linked to the plant's capacity to absorb and retain the iodine from the atmosphere (stomata) and from the soils. Iodine in grasses ranged from 80 to $690 \mu \mathrm{g} / \mathrm{kg}$, with marked species and seasonal differences in iodine content (Alderman and Jones, 1967). Attempts to correlate soil with plant iodine levels have not been successful; iodine's availability from the soil to the plant is generally low (Fuge, 2005). In the present study, the iodine concentrations found in forages fell within the range of values reported in previous studies for pastures (Alderman and Jones, 1967) and agreed with iodine levels found in conserved forages in other countries $(112 \mu \mathrm{g} / \mathrm{kg}$ of DM for hay, $213 \mu \mathrm{g} / \mathrm{kg}$ of DM for grass silage, and $110 \mu \mathrm{g} / \mathrm{kg}$ of DM for maize silage; Trávníček et al., 2004).

Based on the mean iodine levels observed in forages, as well as on calculations for a typical lactating cow diet, these feedstuffs (Table 1) would supply approximately $17 \%$ of the iodine required by the cow (NRC, 2001). Note that using the mean could give a biased estimation because the range of values found was broad for most of the feeds presented. Cereals and oilseed meals are considered poor sources of iodine (Underwood and Suttle, 1999). The average values found in this study for grains and soy products (Table 1) were similar to the values published in nutrient composition tables in France (Sauvant et al., 2004). The ranges reported by McDowell (2003) and Underwood and Suttle 
Table 1. Iodine concentrations in different feed samples collected from farms with high and low milk iodine levels

\begin{tabular}{|c|c|c|c|c|c|c|c|c|}
\hline $\begin{array}{l}\text { Iodine } \\
(\mu \mathrm{g} / \mathrm{kg} \text { of } \mathrm{DM})\end{array}$ & \multicolumn{3}{|c|}{ Forage } & Grains & $\begin{array}{c}\text { Soy } \\
\text { products }\end{array}$ & \multicolumn{2}{|c|}{ Supplements } & $\begin{array}{l}\text { Mineral } \\
\text { mixes }\end{array}$ \\
\hline $\mathrm{SE}$ & 12.1 & 16.5 & 21.8 & 6.5 & 21.2 & - & - & - \\
\hline Median & 107 & 117 & 94 & 40 & 62 & - & - & - \\
\hline Range & 29-517 & 34-569 & $29-479$ & $28-270$ & $29-320$ & $746-14,627$ & $29-35,545$ & $37-322,084$ \\
\hline Total sampled & 63 & 57 & 21 & 47 & 16 & 24 & 56 & 74 \\
\hline
\end{tabular}

${ }^{1}$ Grass and legume silage.

${ }^{2}$ Values higher than $5 \times$ standard deviation from the mean; not included in descriptive statistics.

${ }^{3}$ Samples not included: byproducts with only one sample or samples of sodium bicarbonate; not considered in descriptive statistics.

(1999) are 100 to $200 \mu \mathrm{g} / \mathrm{kg}$ of DM for oilseed meals and 40 to $100 \mu \mathrm{g} / \mathrm{kg}$ of DM for cereal grains. The feeds classified as "supplements" included protein and energy supplements, registered supplements, and custom-made concentrates. Supplements with a standard name and registration number were classified in this study as "registered supplements," whereas those without a name or description were classified as "custom-made concentrates." In total, $50 \%$ of the supplements sampled contained between 1,001 and 10,000 $\mathrm{gg}$ of iodine $/ \mathrm{kg}$ of $\mathrm{DM}, 31 \%$ contained $<1,000 \mu \mathrm{g}$ of iodine $/ \mathrm{kg}$ of $\mathrm{DM}$, and $19 \%$ contained $>10,000 \mu \mathrm{g}$ of iodine $/ \mathrm{kg}$ of DM.

Feeding dairy cows iodine in excess increases concentrations of iodine in milk (Swanson et al., 1990; Kaufmann et al., 1998; Flachowsky et al., 2007). Therefore, iodine concentrations in complete feeds and supplements should not be overlooked. In the present study, most of the supplements sampled (50\%) contained iodine between 1,000 and $10,000 \mu \mathrm{g} / \mathrm{kg}$ of $\mathrm{DM}$; however, $19 \%$ of the supplements sampled contained more than $10,000 \mu \mathrm{g}$ of iodine $/ \mathrm{kg}$ of $\mathrm{DM}$ and required registration in Canada. The use of commercial supplements and premixes in dairy rations should follow the specific label directions to avoid iodine overfeeding. For mineral mixes, the most frequent concentrations found were between 50,000 and 100,000 $\mu \mathrm{g}$ of iodine/ $\mathrm{kg}(42 \%)$. Given that forages provide approximately $17 \%$ of dietary iodine requirements, and assuming no significant supply from supplements, the mineral mix should provide $83 \%$ of the cow's iodine requirements. Mineral mixes with iodine values exceeding 100,000 $\mu \mathrm{g} /$ $\mathrm{kg}$ accounted for $27 \%$ of those sampled. These premixes should be included in very low quantities per cow per day. Some mineral mixes with very high iodine contents are fed to improve reproductive performance. Iodine influences reproductive functions because of its vital role in thyroid function (Hidiroglou, 1979; Dunn and Delange, 2001). Reproductive failure in cases of iodine deficiency is likely to be a secondary manifestation of thyroid dysfunctions resulting in anestrus, irregular estrus, retained placenta, abortion, and stillbirth. Positive influences of iodine supplementation were found in cases of iodine deficiency. However, no reports have shown beneficial effects of iodine overfeeding on reproduction, animal growth, or fattening (Wichtel et al., 1996; Meyer et al., 2008). The use of premixes with very high iodine contents to improve reproduction in early lactation is likely to result in iodine overfeeding, which is unnecessary and should be avoided to preserve milk quality.

Milk iodine levels for the farms in the low and high groups were compared with the same farms' values reported in the previous study (Table 3 in Borucki Castro et al., 2010). For the high group, milk iodine concentration did not differ significantly between the 2 years (2007 and 2008), showing that the elevated iodine content in the milk on some farms was not circumstantial, as the same farms still produced milk with elevated iodine content a year later. For the low group, the differences between 2007 and 2008 were expected, given that the farms selected in the previous study were those with extreme values of milk iodine.

To calculate the $500 \mu \mathrm{g}$ of iodine/ $\mathrm{kg}$ of DM required for lactating dairy cows, the NRC (2001) adopted a physiological approach, in which iodine needs are estimated from the amount of iodine required to sustain the thyroid hormone (thyroxine) secretion rate, assuming certain capture efficiency and recycling rate. The basal requirement of $330 \mu \mathrm{g} / \mathrm{kg}$ of DM daily for nonlactating dairy cows (600 kg of BW) is increased to $500 \mu \mathrm{g} / \mathrm{kg}$ of DM daily, because thyroxine production increases with lactation and because, under normal conditions, approximately $10 \%$ of dietary iodine is secreted in milk. The dietary concentration of iodine offered daily $(\mathrm{mg} / \mathrm{kg}$ of feed $\mathrm{DM})$ was higher for the high group $(1.81 \mathrm{mg} / \mathrm{kg})$ than for the low group $(1.20 \mathrm{mg} /$ 


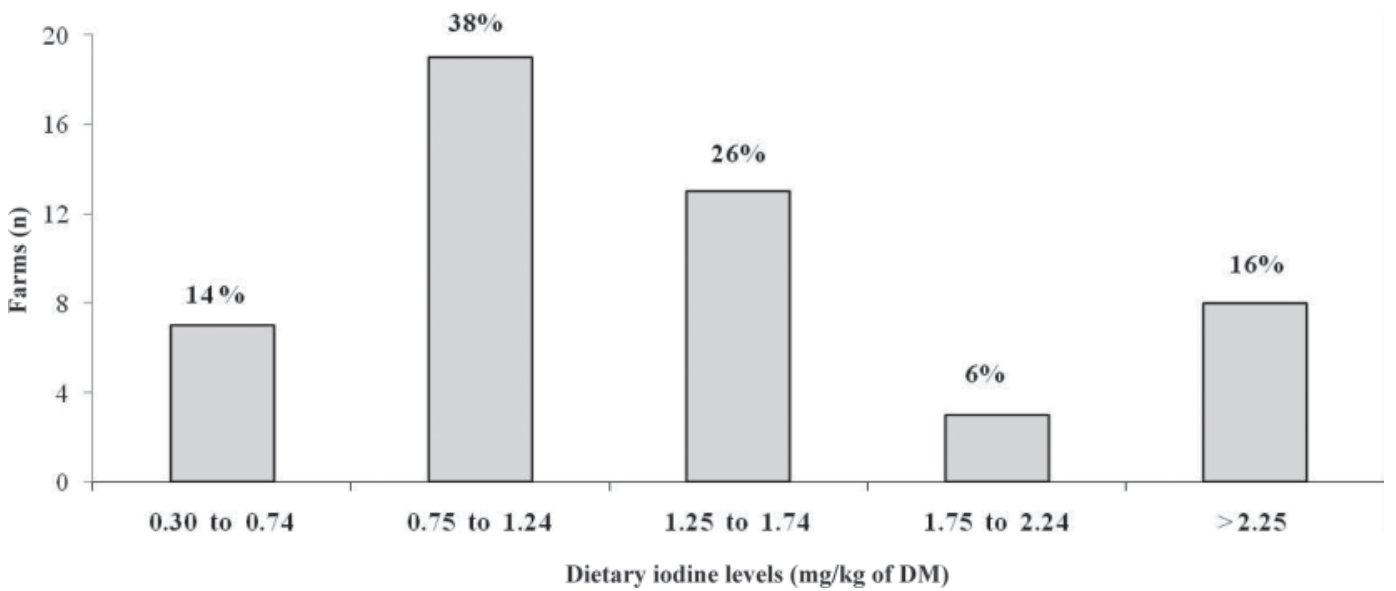

Figure 1. Frequency distribution of farms based on dietary iodine concentrations compared with the recommendations of the NRC (2001).

$\mathrm{kg}$; Table 2). Farms in both groups were feeding 2 and 3 times more dietary iodine than recommended by NRC $(0.5 \mathrm{mg} / \mathrm{kg})$, respectively. Furthermore, the frequency distribution of dietary iodine concentrations (Figure 1) shows that $86 \%$ of the farms sampled were supplying diets with iodine concentrations exceeding recommendations. Feeding more than $70,000 \mu \mathrm{g}$ of iodine per cow per day for longer than $3 \mathrm{wk}$ has been reported to produce intoxication symptoms (Hillman and Curtis, 1980; Olson et al., 1984). Clinical signs of intoxication include persistent cough, hyperthermia, naso-ocular discharge, inappetance, depression, dermatitis, and alopecia (Paulíková et al., 2002).

A significant linear relationship was found between dietary iodine concentration and milk iodine level. The response can be described by the following equation:

$$
\begin{gathered}
y=145( \pm 66.9)+113( \pm 39.4) x, \\
P<0.01, \mathrm{R}^{2}=0.15,
\end{gathered}
$$

where $y$ is milk iodine $(\mu \mathrm{g} / \mathrm{kg})$ and $x$ is dietary iodine concentration $(\mathrm{mg} / \mathrm{kg})$.

The relationship described above means that for every milligram of iodine per kilogram of feed DM, milk iodine would increase by $113 \mu \mathrm{g} / \mathrm{kg}$ of milk (Figure 2). Previous studies (Swanson et al., 1990) found similar relationships in controlled dose-response experiments (milk iodine $=98.6+155.9$ iodine intake; $\mathrm{R}^{2}=0.52$ ). However, the low $\mathrm{R}^{2}$ value suggests that other factors influenced the concentrations of iodine in milk. In a previous study, feeding and milking management practices were shown to have a significant associa-

Table 2. Differences in dietary iodine concentrations between low and high groups ${ }^{1}$

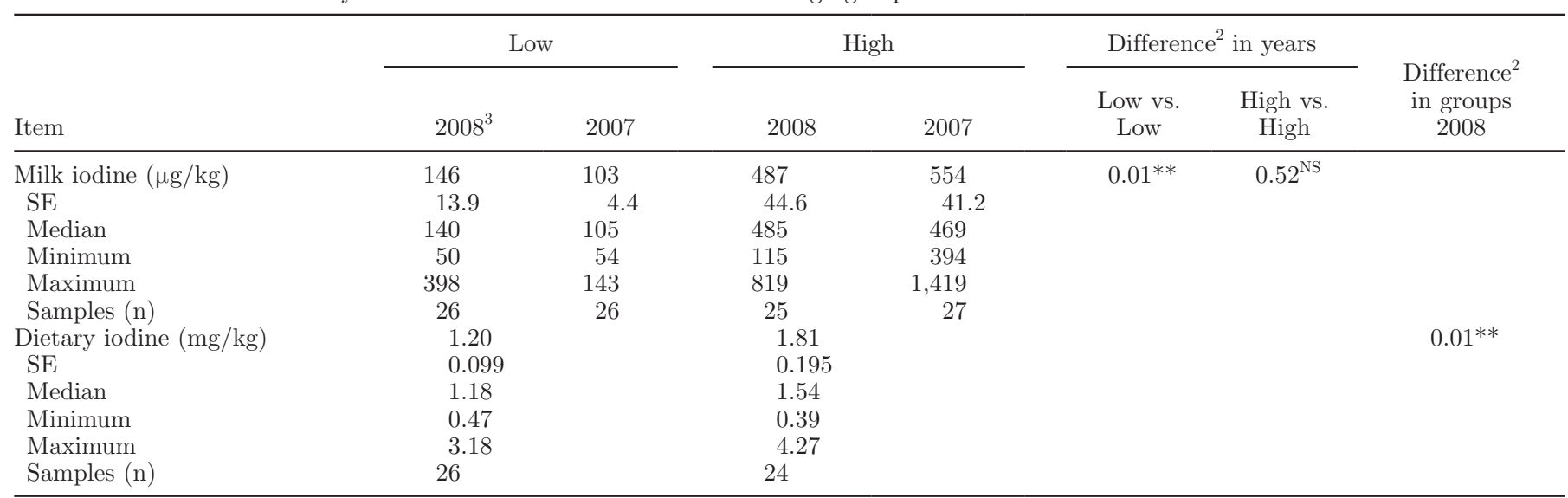

${ }^{1}$ The low and high groups refer to the 30 farms with the lowest and highest milk iodine levels, respectively, of 200 dairy farms in Quebec, Canada, in the study of Borucki Castro et al. (2010).

${ }^{2}$ Significance based on $t$-test $P(\mathrm{~T} \leq \mathrm{t})$ two-tailed, unequal variance Student distribution.

${ }^{3}$ Year in which bulk-tank milk samples were taken.

${ }^{* *} P<0.01$. 


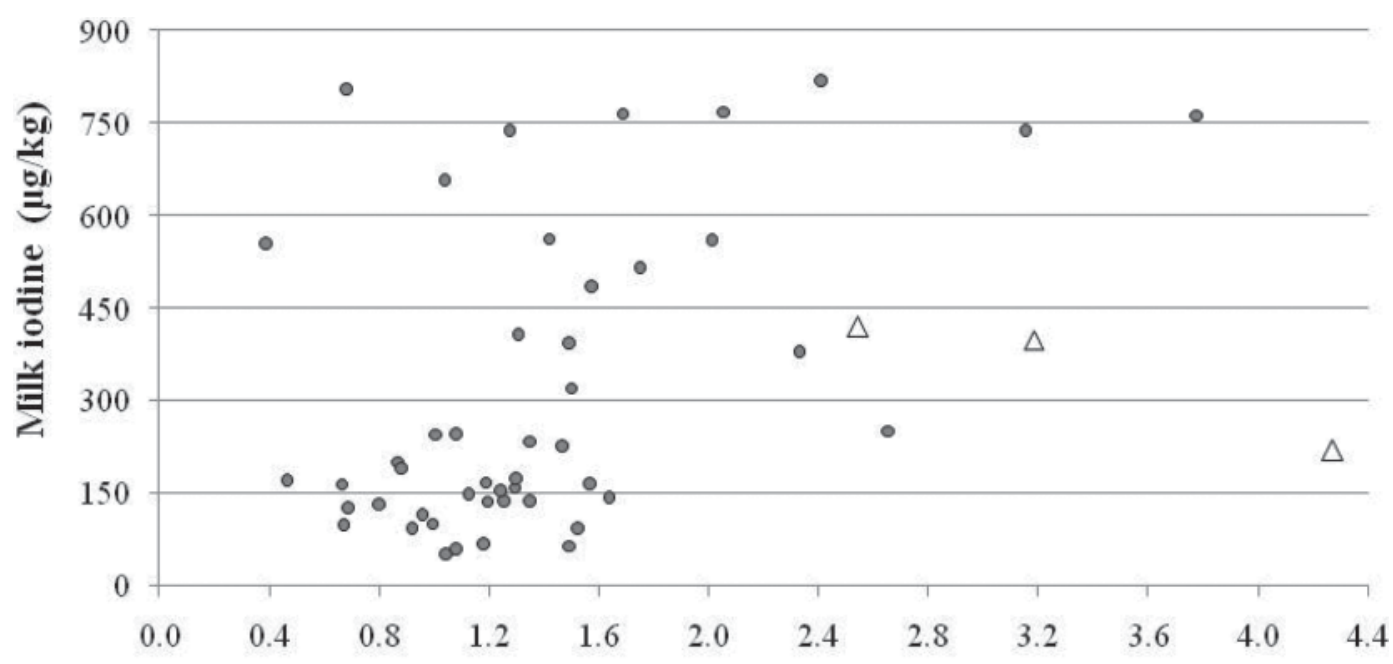

\section{Dietary iodine $(\mathbf{m g} / \mathbf{k g})$}

Figure 2. Relationship between milk iodine levels and dietary iodine estimated from the information provided in the questionnaire. Selected points " $\Delta$ " correspond to farms feeding raw or roasted soybeans or beet pulp.

tion with iodine in milk (Borucki Castro et al., 2010). The form of feeding (in components vs. TMR), teat washing and dipping before milking, and the method of application of teat sanitizers all appeared to influence milk iodine concentrations. Other studies found that factors such as iodine species (iodide vs. iodate) and dietary compounds called goitrogens significantly affected the amount of iodine in milk (Franke et al., 2009). Goitrogens interfere with the normal uptake of iodine; these compounds are present in members of the cruciferous family, including rape and kale (progoitrins and goitrins), as well as in raw soybean, beet pulp, millet, and sweet potato (cyanogenic glycosides). The NRC (2001) suggests the addition of a safety margin above the requirements $(+100 \mu \mathrm{g}$ of iodine $/ \mathrm{kg}$ of DM $)$ to cover the possible effects of goitrogens. The presence of goitrogens could not be determined with certainty in this study because of the presence of commercial protein supplements that may have contained canola meal and other goitrogens. Nevertheless, 2 of the feeds sampled were roasted soybeans and beet pulp. The data from the farms that declared the use of roasted soybeans and beet pulp were clearly out of the trend line in the regression (Figure 2). Further research is required to quantify the effects of goitrogens on milk iodine concentrations. Milking management practices such as the effects of predipping, postdipping, and the use of iodized sanitizers on milk iodine concentrations also require further investigation.

In this study, $86 \%$ of the farms were feeding iodine in excess of requirements. Based on the iodine concentrations found in forages, grains, and soy products, it is unlikely that those feedstuffs are the cause of iodine overfeeding. Mineral mixes, however, supply $83 \%$ of iodine requirements. Attention should therefore be focused on the correct use of mineral supplements in diet formulation to avoid overfeeding. The low $\mathrm{R}^{2}$ value in the linear regression between milk and iodine intakes reflects the fact that other factors do affect iodine concentrations in milk. Milking management practices and the presence of goitrogens in the diet require further investigation.

\section{ACKNOWLEDGMENTS}

The authors thank all the dairy farmers who agreed to participate in this project and thus made it possible. The authors are also grateful to Daniel Lefebvre, Sylvie Lafontaine, and the technicians at Valacta (SteAnne-de-Bellevue, QC, Canada) for the collection and shipment of samples. Financial support from Dairy Farmers of Canada (Ottawa, ON, Canada), Agriculture and Agri-Food Canada (Ottawa, ON, Canada), and Health Canada (Ottawa, ON, Canada) is gratefully acknowledged.

\section{REFERENCES}

Alderman, G., and D. I. H. Jones. 1967. The iodine content of pastures. J. Sci. Food Agric. 18:197-199.

Benkhedda, K., A. Robichaud, S. Turcotte, F. J. Beraldin, and K. A. Cockell. 2009. Determination of total iodine in food samples using inductively coupled plasma-mass spectrometry. J. AOAC Int. 92:1720-1727.

Borucki Castro, S. I., R. Berthiaume, P. Laffey, A. Fouquet, F. Beraldin, A. Robichaud, and P. Lacasse. 2010. Iodine concentration in milk sampled from Canadian farms. J. Food Prot. 73:1658-1663. 
Dahl, L., J. A. Opsahl, H. M. Meltzer, and K. Julshamn. 2003. Iodine concentration in Norwegian milk and dairy products. Br. J. Nutr. 90:679-685.

Dunn, J. T., and F. Delange. 2001. Damaged reproduction: The most important consequence of iodine deficiency. J. Clin. Endocrinol. Metab. 86:2360-2363.

European Food Safety Authority. 2005. Opinion of the Scientific Panel on Additives and Products or Substances used in Animal Feed on the use of iodine in feedingstuffs. Accessed April 2010. http:// www.efsa.europa.eu/en/scdocs/doc/s168.pdf.

European Union. 2005. Regulation EC 1459/2005 amending the conditions for authorisation of a number of feed additives belonging to the group of trace elements. Accessed February 2011. http:// eurlex.europa.eu/LexUriServ/LexUriServ.do?uri=OJ:L:2005:233:0 008:0010:EN:PDF.

Flachowsky, G. 2007. Iodine in animal nutrition and iodine transfer from feed into food of animal origin. Lohmann Information. Vol. 42. Accessed April 2010. http://www.lohmann-information.com/ content/1_i_42_2007-10_artikel11.pdf.

Flachowsky, G., F. Schöne, M. Leiterer, D. Bemmann, M. Spolders, and P. Lebzien. 2007. Influence of an iodine depletion period and teat dipping on the iodine concentration in serum and milk of cows. J. Anim. Feed Sci. 16:18-25.

Franke, K., U. Meyer, H. Wagner, and G. Flachowsky. 2009. Influence of various iodine supplementation levels and two different iodine species on the iodine content of the milk of cows fed rapeseed meal or distillers dried grains with solubles as the protein source. J. Dairy Sci. 92:4514-4523.

Fuge, R. 2005. Soils and iodine deficiency. Pages 417-434 in Essentials of Medical Geology: Impacts of the Natural Environment on Public Health. O. Sellinus, ed. Academic Press, New York, NY.

Hidiroglou, M. 1979. Trace element deficiencies and fertility in ruminants: A review. J. Dairy Sci. 62:1195-1206.

Hillman, D., and A. R. Curtis. 1980. Chronic iodine toxicity in dairy cattle: Blood chemistry, leukocytes, and milk iodide. J. Dairy Sci. 63:55-63.

Kaufmann, S., J. Kursa, V. Kroupova, and W. A. Rambeck. 1998. Iodine in milk by supplementing feed: An additional strategy to erase iodine deficiency. Vet. Med. (Praha) 43:173-178.

Li, M., K. V. Waite, G. Ma, and C. J. Eastman. 2006. Declining iodine content of milk and re-emergence of iodine deficiency in Australia. Med. J. Aust. 184:307.

McDowell, L. R. 2003. Iodine. Pages 305-334 in Minerals in Animal and Human Nutrition. 2nd ed. Elsevier Sci., Amsterdam, the Netherlands.

Meyer, U., K. Weigel, F. Schöne, M. Leiterer, and G. Flachowsky. 2008. Effect of dietary iodine on growth and iodine status of growing fattening bulls. Livest. Sci. 115:219-225.
Moschini, M., M. Battaglia, G. M. Beone, G. Piva, and F. Masoero. 2010. Iodine and selenium carry over in milk and cheese in dairy cows: Effect of diet supplementation and milk yield. Animal 4:147-155.

National Research Council. 2001. Nutrient Requirements of Dairy Cattle. 7th rev. ed. Natl. Acad. Sci., Washington, DC.

Norouzian, M. A., R. Valizadeh, F. Azizi, M. Hedayati, A. A. Naserian, and F. Eftekhari Shahroodi. 2009. The effect of feeding different levels of potassium iodide on performance, $T_{3}$ and $T_{4}$ concentrations and iodine excretion in Holstein dairy cows. J. Anim. Vet. Adv. 8:111-114.

Olson, W. G., J. B. Stevens, J. Anderson, and D. W. Haggard. 1984. Iodine toxicosis in six herds of dairy cattle. J. Am. Vet. Med. Assoc. 184:179-181.

Paulíková, I., G. Kováč, J. Bíreš, Š. Paulík, H. Seidel, and O. Nagy. 2002. Iodine toxicity in ruminants. Vet. Med. (Praha) 47:343-350.

Roti, E., and E. D. Uberti. 2001. Iodine excess and hyperthyroidism. Thyroid 11:493-500.

Sauvant, D., J. M. Perez, and G. Tran. 2004. Tables de Composition et de Valeur Nutritive des Matières Premières Destinées aux Animaux d'Élevage: Porcs, Volailles, Bovins, Ovins, Caprins, Lapins, Chevaux, Poissons. 2nd rev., corr. ed. INRA, Paris, France.

Schöne, F., M. Leiterer, P. Lebzien, D. Bemmann, M. Spolders, and G. Flachowsky. 2009. Iodine concentration of milk in a dose-response study with dairy cows and implications for consumer iodine intake. J. Trace Elem. Med. Biol. 23:84-92.

Scientific Committee on Food. 2002. Opinion of the Scientific Committee on Food on the tolerable upper intake level of iodine. Accessed April 2010. http://ec.europa.eu/food/fs/sc/scf/out146_en.pdf.

Swanson, E. W., J. K. Miller, F. J. Mueller, C. S. Patton, J. A. Bacon, and N. Ramsey. 1990. Iodine in milk and meat of dairy cows fed different amounts of potassium iodide or ethylenediamine dihydroiodide. J. Dairy Sci. 73:398-405.

Trávníček, J., V. Kroupová, and M. Šoch. 2004. Iodine content in bulk feeds in western and southern Bohemia. Czech J. Anim. Sci. 49:483-488.

Underwood, E. J., and N. F. Suttle. 1999. Iodine. Pages 343-373 in The Mineral Nutrition of Livestock. 3rd ed. CABI Publishing, New York, NY.

Wichtel, J. J., A. L. Craigie, D. A. Freeman, H. Varela-Alvarez, and N. B. Williamson. 1996. Effect of selenium and iodine supplementation on growth rate and on thyroid and somatotropic function in dairy calves at pasture. J. Dairy Sci. 79:1865-1872. 